\title{
OPENBARE NUTSBEDRIJVEN: GRONDSLAGEN EN HUN IMPLICATIES VOOR DE PRIJSZETTING*)
}

\author{
door Drs. G. J. van Helden
}

\section{Inleiding}

Traditioneel wordt het begrip ,openbaar nutsbedrijf" van toepassing verklaard voor die organisaties, welke zich hebben toegelegd op de produktie, distributie en verkoop van elektriciteit, gas, water, het (openbare) massavervoer, of de telefonische, telegrafische en postale communicatie. Een in het oog springende overeenkomst tussen deze organisaties is dat zij op een of andere wijze zijn onderworpen aan overheidstoezicht. Om vanuit deze gemeenschappelijke eigenschap het begrip ,openbaar nutsbedrijf" af te bakenen, willen we trachten in dit artikel de volgende twee vragen te beantwoorden.

(1) Welke zijn de redenen die overheidstoezicht bij openbare nutsbedrijven noodzakelijk of wenselijk maken?

(2) Op welke wijze vindt het overheidstoezicht plaats, c.q. moet dit plaatsvinden?

Hoewel een simultane beantwoording van beide vragen voor een adequate omschrijving van het begrip „openbaar nutsbedrijf" de voorkeur verdient, opteren wij in dit artikel, teneinde ons betoog enigszins te structureren, voor een gescheiden beantwoording van de twee vragen. De eerste vraag komt aan de orde in par. 2. Aan de tweede vraagstelling besteden we slechts aandacht voor zover deze zich toespitst op de prijszettingsconsequenties van het overheidstoezicht. In par. 3 bespreken we enkele algemene principes terzake en in par. 4 gaan we in op de specifieke prijszettingsprincipes die relevant zijn wanneer het openbare nutsbedrijf wordt geconfronteerd met een periodiek gedifferentieerde vraag, terwijl produktie op voorraad onmogelijk is.

Ons betoog is zo algemeen mogelijk opgezet: het is in principe geldig voor alle openbare nutsbedrijven. Mede gegeven het korte bestek van dit artikel, heeft dit uitgangspunt tot consequentie dat een hoog abstractieniveau onvermijdbaar is. Men zal dan ook geen uitgewerkt schema van principes en procedures voor het overheidstoezicht van openbare nutsbedrijven behoeven te verwachten. Dit artikel bevat slechts een ,,aanzet tot het denken over" de grondslagen van openbare nutsbedrijven.

\section{Bestaansgronden}

Wij definiëren een openbaar nutsbedrijf als een bedrijf dat onder toezicht van de overheid is gesteld om te voorkomen dat een particuliere exploitatie schade toebrengt aan de maatschappelijke welvaart; deze schade zou ontstaan enerzijds door ,uitbuiting" van een (natuurlijke) monopoliepositie en anderzijds omdat specifieke goedereneigenschappen dan in onvoldoende mate in het beleid tot uitdrukking worden gebracht. De in deze definitie genoemde bestaansgronden voor een openbaar nutsbedrijf, i.c. het natuurlijke monopolie en specifieke goedereneigenschappen, worden respectievelijk in de para-

\footnotetext{
*) Dit artikel berust grotendeels op: G. J. van Helden, Economie van openbare nutsbedrijven, Me moranda van het Instituut voor Economisch Onderzoek, nr. 12. Groningen, 1976.
}

$m a b \quad b l z .528$ 
grafen 2.1. en 2.2. van een inhoud voorzien. Het in verband met deze bestaansgronden gehanteerde begrip "maatschappelijke welvaart" wordt eerst in par. 3 gedefinieerd. We gaan er evenwel van uit dat dit begrip intuitief voldoende inhoud heeft om in dit stadium van ons betoog al te worden gebruikt.

\subsection{Het natuurlijke monopolie}

Er zijn omstandigheden waaronder een bepaalde markt van gegeven omvang en structuur tegen de laagst mogelijke kosten kan worden voorzien, indien het aanbod slechts in handen is van één onderneming. Als er in deze situatie niettemin op een bepaald moment meerdere aanbieders zouden zijn, heeft dit een tweeledig gevolg. In de eerste plaats zullen de gemiddelde kosten hoger zijn dan die welke zich bij een monopolist voordoen. In de tweede plaats zal een situatie van concurrentie slechts tijdelijk kunnen bestaan. ${ }^{1}$ ) Immers, de onderneming die het grootste aandeel in de markt heeft, doet zijn aanbod tegen (relatief) de laagste kosten, waardoor zijn mede-aanbieders , uit de markt worden geprijsd". Concurrentie leidt in zo'n geval automatisch tot monopolie, of nog sterker: concurrentie elimineert zichzelf. Op grond hiervan spreekt men van een ,natuurlijk monopolie". Om te voorkomen dat de (natuurlijke) monopolist zijn marktpositie weet uit te buiten, met name door het vragen van prijzen die de kosten aanzienlijk te boven gaan, hetgeen schadelijk is voor de maatschappelijke welvaart, wordt deze monopolist onder toezicht van de overheid gesteld. Dit overheidstoezicht noemt men requlering. De aard van deze regulering komt ter sprake in par. 3 van dit artikel. Nú is van belang de vraag: welke factoren maken dat onder monopolie een bepaalde markt tegen de laagste kosten kan worden voorzien?

In de eerste plaats moet in dezen worden vermeld het bestaan van ,economies of scale". Hieronder verstaat men een situatie waarin de ,lange-termijngemiddelde (en marginale)-kosten" afnemend zijn. Dit betekent verminderende kosten bij een capaciteitsuitbreiding. Bijv.: de capaciteitskosten per MegaWatt (MW) bij een elektrische centrale van $600 \mathrm{MW}$ zijn lager dan die bij een centrale van $100 \mathrm{MW}$, welke op zich weer lager zijn dan de capaciteitskosten van een $10 \mathrm{MW}$-centrale.

In de tweede plaats zijn er argumenten voor kostendegressie, welke relevant zijn bij een gegeven capaciteit. Naar analogie van het ,economies of scale"-argument zou men deze vorm van kostendegressie kunnen typeren met behulp van een afnemende ,korte-termijn-gemiddelde (en marginale)kostencurve". We noemen in dezen een drietal deel-argumenten.

(1) De technologie, meestal van een bepaald distributiesysteem, is van zodanige aard dat de voorziening van een bepaalde markt door meer dan één onderneming zou leiden tot een duplicatie of multiplicatie van produktiemiddelen, hetgeen een verspilling zou impliceren. De distributietechnologie van bijv. elektriciteit, gas of telefoonverkeer vereist nl. een nauwe verbinding tus-

\footnotetext{
1) Behalve wanneer de verschillende ondernemingen elkaar bij a fspraak behoeden voor concurrentie (bijv. kartels, hoewel deze veelal nauwelijks een enigszins stabiele marktsituatie scheppen), of wanneer de overheid monopolievorming tracht te verhinderen. Zie verder: R. A. Posner, Natural Monopoly and its Regulation, Stanford Law Review, 1969, blz. 547-643, i.h.b. blz. 585.
} 
sen het produktiesysteem enerzijds en de consumenten anderzijds. In dat geval zou het een verspilling betekenen, indien in een bepaalde marktlocatie elektriciteitskabels, gasbuizen of telefoonkabels van verschillende ondernemingen naast elkaar liggen. ${ }^{2}$ )

(2) Het zogenaamde diversiteitsverschijnsel leidt tot de kleinste onderbezetting, indien de markt door slechts één onderneming van de gevraagde goederen wordt voorzien. Diversiteit houdt in dat de som van de maximale vraag voor een aantal verbruikers (of groepen van verbruikers) groter is dan de maximale som van hun vraag. Dit betekent dat voor verschillende verbruikers (of groepen van verbruikers) de maximale vraag niet gelijktijdig optreedt. $\mathrm{Nu}$ geldt in het algemeen dat - hoe groter het aantal verbruikers - des te groter de verscheidenheid in hun vraagpatroon, dus ook des te groter de diversiteit. In zo'n geval kan een monopoliebedrijf een bepaalde totaal-vraag met minder capaciteit opvangen dan wanneer in diezelfde vraag door twee of meer bedrijven moet worden voorzien. Met andere woorden, het monopoliebedrijf werkt met een relatief kleinere onderbezetting; de capaciteitskosten zijn dan navenant lager.

$\mathrm{Er}$ is nog een additionele reden waardoor het diversiteitsargument aan belang wint. Voor de meeste openbare nutsbedrijven geldt $\mathrm{nl}$. dat de mogelijkheid tot produktie op voorraad praktisch ontbreekt. Hierdoor moet een nutsbedrijf haar capaciteit steeds afstemmen op de maximale vraag. Deze technologische restrictie impliceert dat er in perioden van een lagere dan de maximale vraag overcapaciteit moet worden toegestaan. Deze overcapaciteit kan evenwel worden beperkt, indien een nutsbedrijf kan ,profiteren" van een zo groot mogelijke diversiteit bij haar vragers. De beste garantie hiertoe is een monopoliestatus.

(3) Indien ondernemingen worden geconfronteerd met relatief grote investeringen in hun produktie- en distributie-apparaat, dan zal - bij een gegeven capaciteit - een toename van de vraag leiden tot een sterke afname van de gemiddelde (korte termijn) kosten. Deze produktiestructuur maakt dat een goede, liefst zo volledig mogelijke bezetting van een gegeven capaciteit van groot belang is. Dit laatste nu is onder een monopolie beter realiseerbaar dan ingeval meerdere ondernemingen (elk met hun onderbezetting) als aanbieders optreden. Dat de investeringen bij openbare nutsbedrijven (bijv. in relatie tot de omzet, d.i. de omlooptijd van het vermogen) groot zijn, blijkt uit Amerikaans onderzoek, waarbij het betrokken verhoudingsgetal een factor vier verschilt, wanneer we openbare nutsbedrijven vergelijken met de industrie als geheel. ${ }^{3}$ ) Het is overigens van belang op te merken dat het hier gesignaleerde argument van de korte termijn kostendegressie vooral relevant is, wanneer de investeringen relatief groot zijn, terwijl tevens sprake is van aanzienlijke ondeelbaarheden.

De keuze van de in deze paragraaf gegeven argumenten voor een natuurlijk monopolie is ingegeven door de gedachte dat deze argumenten specifiek gel-

$\left.{ }^{2}\right)$ Zie met name J. C. Bonbright. Principles of Public Utility Rates, New York: Columbia University Press, 1961, blz. 12-13.

3) Zie P. J. Garfield en W. F. Lovejoy, Public Utility Economics, Englewood Cliffs (N.J.): Prentice Hall, 1964, blz. 22-23.

ma b blz. 530 
den voor openbare nutsbedrijven. ${ }^{4}$ ) Dit betekent niet dat de betrokken argumenten niet tevens een rol kunnen spelen bij marktstructuren van bepaalde particuliere ondernemingen, of bij overheidsbedrijven, geen openbare nutsbedrijven zijnde. Wèl zij benadrukt dat juist de combinatie van de gebruikte argumenten, alsmede hun kwantitatieve belang de natuurlijke monopoliestatus van openbare nutsbedrijven vastleggen.

\subsection{Goedereneigenschappen}

Vaak wordt de grondslag van een openbaar nutsbedrijf tevens in verband gebracht met de specifieke eigenschappen van de geproduceerde (en verkochte) goederen. Met betrekking tot deze goederen, door ons kortweg aangeduid als „,openbare nutsgoederen", wordt dan gesteld: ze zijn van vitaal belang voor de maatschappij, ze zijn onmisbaar en worden in brede lagen van de bevolking gebruikt (of woorden van gelijke strekking). ${ }^{5}$ ) Het zijn dan (mede) deze goedereneigenschappen die een bepaalde vorm van overheidstoezicht rechtvaardigen. Dat openbare nutsgoederen van ,,vitaal belang" zouden zijn, is op zich een loze uitspraak. Er zijn immers voldoende produkten, waarvan men evenmin het vitale belang zal ontkennen, maar die - in elk geval traditioneel gezien - niet het predicaat openbaar nutsgoed krijgen opgelegd; men denke in dit verband aan olie, woningen, brood etc. De enige manier om het vitale belang als substantiële grondslag te kunnen accepteren, is na te gaan welke concrete inhoud aan dit argument bij openbare nutsbedrijven wordt gegeven. Dit blijkt het volgende resultaat op te leveren.

(a) Openbare nutsgoederen zijn onontbeerlijke bestanddelen van de huishoudelijke consumptie, of essentiële hulpbronnen bij vele produktieprocessen. Om die reden is een ongestoorde levering van de desbetreffende goederen van groot belang. Men spreekt in dit verband over de ,leveringsplicht", die overigens haar exclusiviteit bij openbare nutsgoederen naar onze mening vooral ontleent aan de omstandigheid dat voor de betrokken goederen niet alleen voor de producent (zie par. 2.1.), maar ook voor de consument de onmogelijkheid van voorraadhouden geldt.

(b) Een overweging is voorts dat openbare nutsgoederen op een groot aantal plaatsen beschikbaar moeten zijn. Zo bestelt de postdienst niet alleen brieven in stedelijke concentraties, maar ook in bijv. de IJsselmeerpolders; vergelijkbare voorbeelden zijn er voor andere openbare nutsgoederen. Het is gebruikelijk in dezen het begrip ,,aansluitingsplicht" te hanteren.

(c) Een hiermee verbonden overweging is dat men eventuele kostenverschillen, die met de aard van de lokatie van levering samenhangen, niet (of niet volledig) tot uitdrukking wil laten komen in de prijs van het onderhavige goed. Bijv.: de aansluitingskosten van een perifeer gelegen boerderij worden

\footnotetext{
4) Empirisch onderzoek heeft overigens uitgewezen dat bij elektriciteitsproduktie nauwelijks meer sprake is van ,economies of scale" (althans boven $600 \mathrm{MW}$ ), zodat als argument voor een natuurlijk monopolie uitsluitend de korte termijn-kostendegressie resteert. Zie E. Berlin, C. J. Cichetti en W. J. Gillen, Perspective on Power: a Report to the Energy Policy Project of the Ford Foundation, Cambridge Mass.: Ballinger, 1974, blz. 6-11.

5) Zie bijv. P. J. Garfield en W. F. Lovejoy, op. cit., blz. 1; N. J. M. van Biezen, Openbare nutsbedrijven. Tijdschrift voor Marketing, 1972, blz. 208-216, i.h.b. blz. 208. Er zijn ook auteurs die het betrokken argument categorisch a fwijzen; vgl. J. C. Bonbright. op. cit., blz. 9.
} 
door het betrokken elektriciteitsbedrijf slechts voor een deel in de prijs geincorporeerd; het verlies dat men hierdoor leidt wordt terugverdiend op verbruikers (bijv. in een stedelijke concentratie) waarvoor de aansluitkosten relatief laag zijn. ${ }^{6}$ ) Een ander sprekend voorbeeld is de in stand houding van zogeheten onrendabele buslijnen of treinverbindingen. De hier gesignaleerde overweging zou men kunnen kwalificeren als ,het streven naar een zekere uniformiteit in de leveringsvoorwaarden".

De onder (a), (b) en (c) genoemde grondslagen voor overheidstoezicht op de produktie en verkoop van openbare nutsgoederen berusten voor een niet onbelangrijk deel op een bepaalde vorm van ,,solidariteit" die voor de desbetreffende goederen opportuun wordt geacht. ${ }^{7}$ ) Men stelt nl. impliciet: ,,deze goederen moeten voor iedereen beschikbaar zijn, zonder dat de voorwaarden waaronder levering plaats vindt, ondanks duidelijke kostenverschillen, al te sterk verschillen". Ter voorkoming van enig misverstand zij benadrukt dat men de hier genoemde concretiseringen van het „,vitale belangargument” bij openbare nutsgoederen niet volstrekt consistent in de praktijk terugvindt. Men denke in dit verband aan gebieden, waar bepaalde openbare nutsgoederen niet beschikbaar zijn, bijv. in Slochteren, waar men het tot voor kort moest stellen zonder aardgas. Ook tariefverschillen zijn voor bepaalde openbare nutsgoederen - met name elektriciteit, water en gemeentelijk of regionaal busvervoer - eerder regel dan uitzondering. ${ }^{8}$ )

Het valt verder buiten het bestek van ons betoog openbare nutsbedrijven te vergelijken met enerzijds particuliere ondernemingen en anderzijds de ,,non-profit"-organisaties, die niet worden gekwalificeerd als openbaar nutsbedrijf. We volstaan met de opmerking dat de onderhavige vergelijking zich kan toespitsen op de in deze paragrafen vermelde grondslagen voor openbare nutsbedrijven, i.c. het natuurlijke monopolie en de specifieke goedereneigenschappen. ${ }^{9}$ )

\section{Algemene implicaties voor de prijszetting}

In deze paragraaf bezinnen we ons op de vraag welke beleidsmatige consequenties de in par. 2 geïntroduceerde grondslagen hebben voor de prijszetting. Voor een goed begrip van ons betoog is het zinvol vooraf enkele kanttekeningen te plaatsen.

- In de eerste plaats beschouwen we uitsluitend de prijszettingsconsequenties, voor zover deze voortvloeien uit het argument van het natuurlijke monopolie. We gaan ervan uit dat de specifieke overwegingen betreffende de

6) Men spreekt in dit verband over „kruisgewijze subsidiëring" van consumentengroepen.

7) Het is deze reden die aan openbare nutsgoederen, althans voor een deel, een ,merit-status" verleent. Hiermee wordt bedoeld dat de overheid politieke argumenten hanteert om de consumentensouvereiniteit ten aanzien van bepaalde goederen te doorkruisen. Zie verder G. J. van Helden, op. cit., par. I. 3.

8) Deze verschillen hangen overigens in belangrijke mate samen met de onderhavige overheidsorganisatie. Elektriciteits- en vervoerstarieven worden nl. primair op gemeentelijk of provinciaal overheids niveau vastgesteld, waardoor regionale verschillen in de hand worden gewerkt. Een overtuigend onder zoek inzake tariefverschillen bij elektriciteit (kleinverbruikers) treft men aan in de Consumentengids dec. 1975 .

9) Zie G. J. van Helden, op. cit., par. I. 4.

mab blz. 532 
goedereneigenschappen reeds zijn geoperationaliseerd in de vorm van bepaalde randvoorwaarden. Deze randvoorwaarden hebben betrekking op zowel de vraagspecificatie (voor welke consumenten is er een leverings- en aansluitingsplicht?) als de kostenspecificatie (welke kostencomponenten mogen wèl en welke mogen niet worden verbijzonderd naar de verschillende ,consumententypen”?).

- In de tweede plaats beperken we ons in deze paragraaf tot die situatie waarin de natuurlijke monopolist zijn produkt aanbiedt aan een homogene markt. Deze vooronderstelling doet de realiteit geweld aan. Juist een monopolist zal nl. zijn markt willen (en kunnen) opsplitsen in verschillende segmenten. Elk segment krijgt dan een eigen prijs toegewezen. In par. 4 van dit artikel wordt aandacht geschonken aan het probleem van de prijsdifferentiatie, waarbij we in het bijzonder een periodiek gedifferentieerde vraagspecificatie vooronderstellen die bij openbare nutsbedrijven hoogst relevant is.

- Voorts zij opgemerkt dat we ons uitsluitend bezighouden met de prijszetting, waarmee niet gezegd wil zijn dat dit het enige beleidsfacet is dat bij de regulering van openbare nutsbedrijven van belang is. Vele andere beleidsfacetten, zowel doelstellingen als instrumenten, kunnen worden genoemd. We volstaan hier met een literatuurverwijzing. ${ }^{10}$ )

De prijszettingsconsequenties die de toezicht houdende overheidsinstantie moet verbinden aan het bestaan van een natuurlijke monopoliepositie zullen we volgens tweeërlei opvatting aan de orde stellen. Allereerst in par. 3.1. waarbij we een welvaartseconomische conceptie introduceren. In par. 3.2. wordt vervolgens aandacht besteed aan een conceptie die in ,de" praktijk vigeert.

\subsection{Een welvaartseconomische conceptie: de marginale kostenregel}

De overheidsinstantie die wordt geconfronteerd met het recht (of zelfs de plicht) invloed uit te oefenen op het producentengedrag van natuurlijke monopolies, kan hiertoe te rade gaan bij de welvaartseconomie. De welvaartseconomie zal stellen dat het producentengedrag optimaal is, indien het verschil tussen baten en kosten, dat dit gedrag genereert, zo groot mogelijk is. Dit kan als volgt worden geoperationaliseerd.

We gaan uit van een (natuurlijke) monopolist, waarvan prijsafzetfunctie en kostenfunctie gegeven zijn. In figuur 1 zijn deze grafisch voorgesteld. Produktie en verkoop van het betrokken produkt genereren zowel baten als kosten. De baten worden voorgesteld door de oppervlakte onder de prijsafzetfunctie; impliciet wordt nl. de prijs "langs" de prijsafzetfunctie opgevat als de waarde van het produkt voor de vrager. Als in figuur $1 \mathrm{FF}^{\prime}$ de marginale kostenfunctie voorstelt (deze is conform de definitie van een natuurlijk monopolie, afnemend), dan worden de kosten van de produktie in de figuur weergegeven door de oppervlakte onder de curve $\mathrm{FF}^{\prime}$. Het gaat er nu om die hoeveelheid te kiezen, waarbij het verschil tussen baten en kosten, d.i. het maatschappelijk surplus, maximaal is. Uit figuur 1 valt eenvoudig af te leiden

10) Zie J. M. McKie, Regulation of the Free Market: the Problem of Boundaries, Bell Journal of Economics and Management Science, 1970 , blz. 6-26, i.h.b. blz. 7.

ma $\quad b \quad b l z .533$ 


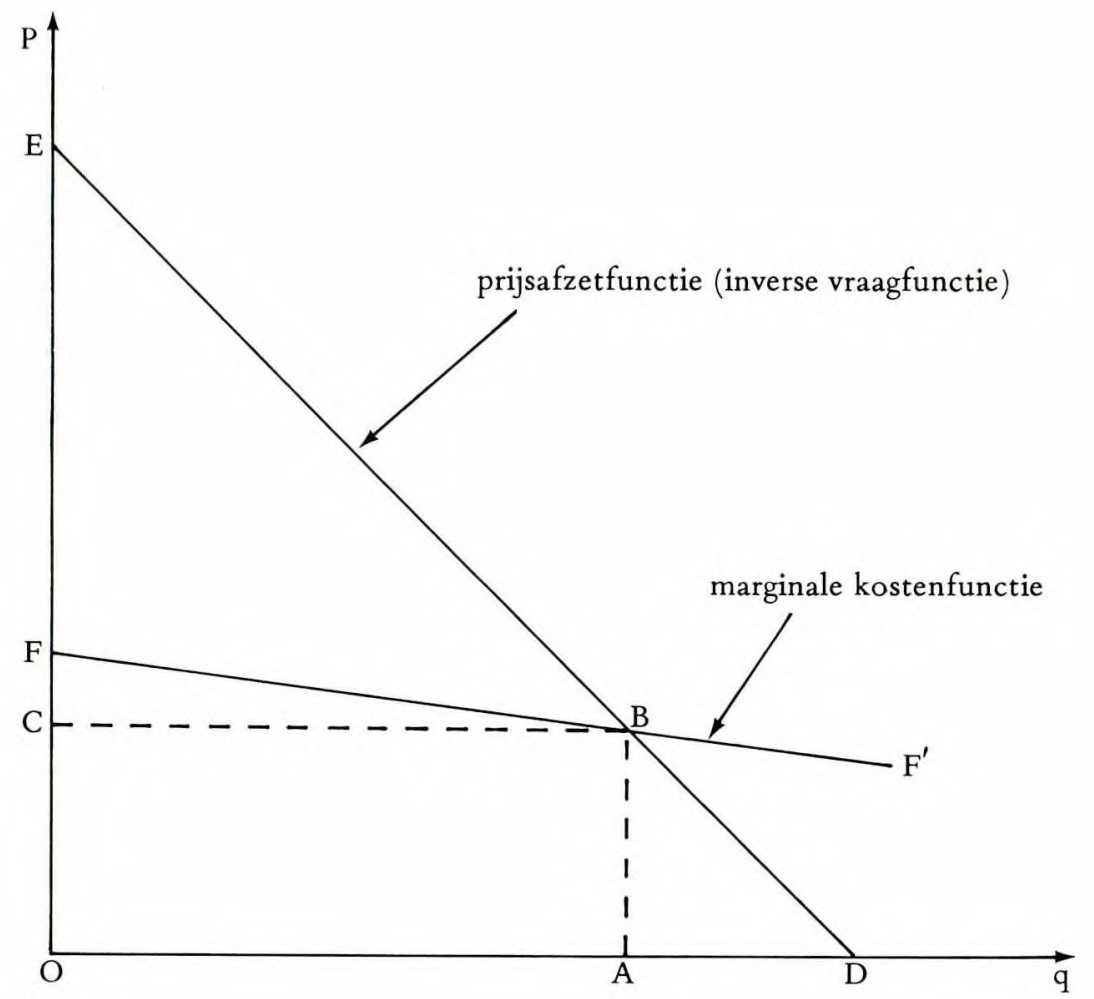

Figuur 1

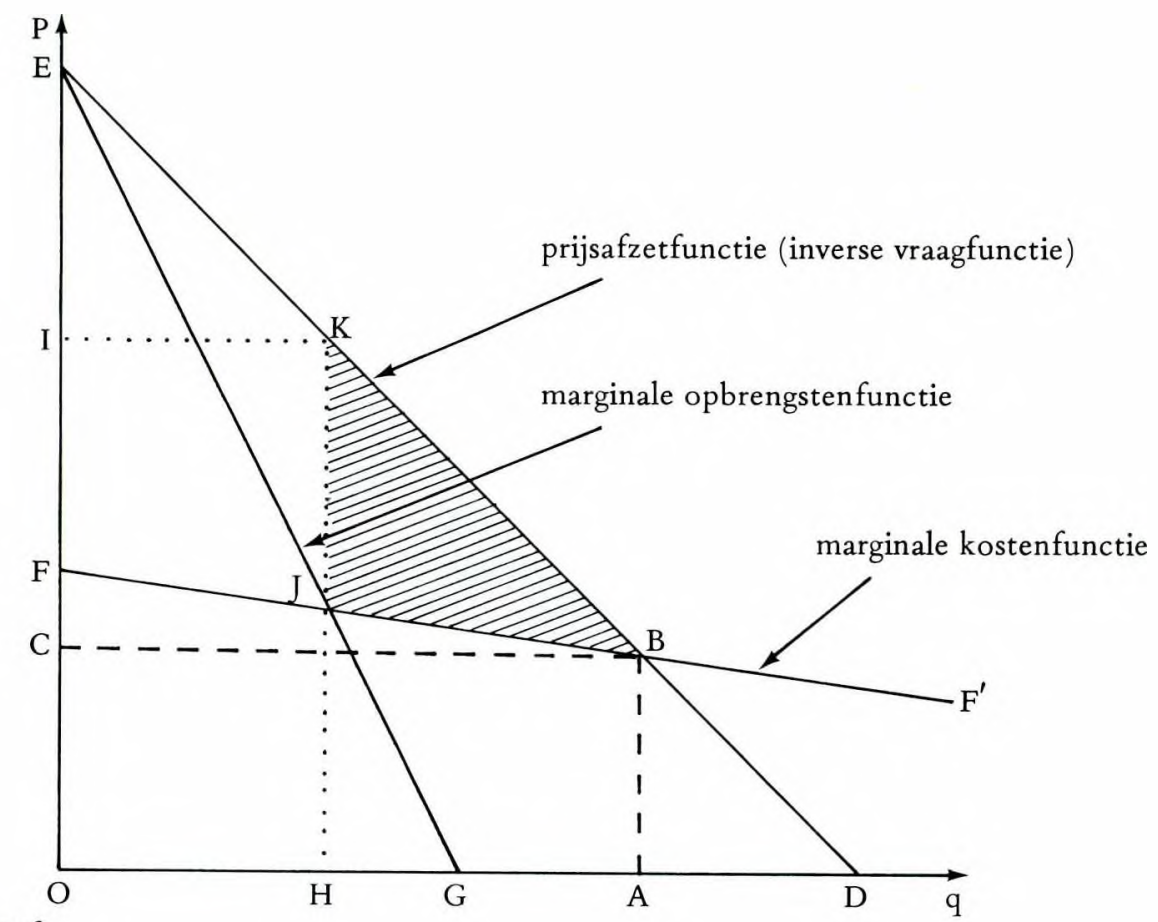

Figuur 2

$m a b \quad$ blz. 534 
dat dit de hoeveelheid OA zal zijn: ${ }^{1}{ }^{1}$ ) de daarbij behorende prijs is OC. Het maatschappelijk surplus wordt dan voorgesteld door de oppervlakte van de driehoek FBE. De welvaartsoptimale prijs blijkt gelijk te zijn aan de marginale kosten. Men spreekt derhalve over de ,marginale kostenregel".

Stel dat een (natuurlijke) monopolist niet door overheidsingrijpen aan banden wordt gelegd en dat deze monopolist streeft naar winstmaximalisatie, hoe groot is dan het welvaartsverlies? We herhalen figuur 1 en tekenen daarin ook de winstmaximaliserende oplossing (zie figuur 2). Deze oplossing, bij het snijpunt van de marginale kosten- en marginale opbrengstenfunctie correspondeert met een hoeveelheid $\mathrm{OH}$ bij een prijs $\mathrm{OI}$. Het welvaartsverlies is dan gelijk aan de oppervlakte van de driehoek JBK, gearceerd in figuur 2; hiertoe worden surplus- en winstmaximalisatie onderling vergeleken.

Het bestek van ons betoog laat niet toe dat we uitgebreid ingaan op de in het voorgaande impliciet gehanteerde welvaartsconceptie. We volstaan daarom met het noemen van enkele vooronderstellingen. ${ }^{12}$ )

(a) De marginale kostenregel geeft uitsluitend een indicatie voor de hoeveelheid produkt die moet worden afgezet (en daarmee ook voor de te hanteren prijs). Voor andere beslissingsvelden, bijv. met betrekking tot de aanwending van produktiemiddelen, doet deze regel geen aanbevelingen.

(b) Bij afnemende marginale kosten (i.c. bij een natuurlijk monopolie) leidt toepassing van de marginale kostenregel tot een verliesgevende exploitatie. In figuur 1 en 2 wordt het verlies voorgesteld door de oppervlakte van de driehoek CBF. Veelal stelt men evenwel als eis aan openbare nutsbedrijven dat deze tenminste kostendekkend moeten zijn. Bij een homogene markt, zoals in deze paragraaf voor het voetlicht gebracht, verliest de marginale kostenregel dan haar betekenis. Bij een heterogene markt daarentegen (waarbij opsplitsing in marktsegmenten mogelijk is) kunnen marginale kostenregel en de eis tot kostendekking gezamenlijk van belang zijn voor de prijszetting. Dit zal in par. 4 nog nader blijken.

(c) Impliciet wordt aangenomen dat alle andere sectoren dan de openbare nutssector welvaartsoptimaal functioneren, i.c. opereren onder volledige mededinging. Aangezien dit in de realiteit vaak niet het geval is, moet de marginale kostenregel, die men "first best" noemt, worden geamendeerd in een ,,second best"-regel, zeker wanneer de betrokken particuliere goederen, d.z. de hiervoor bedoelde ,,andere" sectoren, vraag- of kostenrelaties onderhouden met de beschouwde openbare nutsgoederen.

(d) Er wordt vanuit gegaan dat eventueel optredende externe effecten bij produktie en consumptie van het openbare nutsgoed (en alle andere goederen) kunnen worden verwaarloosd.

(e) Bovendien betekent het gekozen welvaartscriterium dat men indifferent staat tegenover zowel de inkomensverdeling in de uitgangssituatie als die welke ontstaat na implementatie van de verrichte aanbevelingen.

11) Een bewijs uit het ongerijmde kan aan de hand van figuur 1 eenvoudig worden geleverd. Als $\mathrm{q}<O A$, zal elke vergroting van $\mathrm{q}$ (de hoeveelheid) leiden tot een vergroting van het surplus; de baten zijn immers hoger dan de kosten. Is daarentegen $\mathrm{q}>\mathrm{OA}$, dan zal een inkrimping van de hoeveelheid tot een surplusvergroting leiden (de kosten zijn hoger dan de baten). Hieruit volgt dat bij $q=O A$ het surplus maximaal is. Voor een analytisch bewijs, zie G. J. van Helden, op. cit., par. II. 2.1.

12) Zie verder G. J. van Helden, op. cit., par. II. 2 en hoofdstuk III. 


\subsection{De praktijk: ,rate of return"'-regulering}

Het reguleringsoogmerk dat samenhangt met de grondslag van het natuurlijke monopolie is uitbuitingsverschijnselen, die zich bij een particuliere exploitatie zouden kunnen voordoen, te voorkomen. In de praktijk wordt deze reguleringsdoelstelling veelal geoperationaliseerd door het openbare nutsbedrijf een bepaald winstplafond op te leggen. Dit winstplafond, dat lager is dan de maximaal bereikbare winst, word t vaak niet gespecificeerd als een absoluut bedrag per periode. De winstrestrictie wordt daarentegen gegoten in de vorm van een maximaal toelaatbare winstvoet (een ,fair rate of return"), in welk geval de winst wordt gerelateerd aan het geinvesteerde vermogen. De „fair rate of return" is dus een relatieve grootheid die slechts functioneert als beperking voor het beleid van een openbaar nutsbedrijf. Binnen het kader van deze beperking kan het nutsbedrijf zelfstandig bepaalde doelstellingen nastreven, zoals we hierna in par. 4 nog zullen zien.

Om de invloed van de „fair rate of return"-restrictie op de prijszetting te kunnen laten zien, introduceren we eerst het begrip "revenue requirement" (te vertalen als „opbrengstdoelstelling”) dat bij de regulering van openbare nutsbedrijven een centrale rol speelt. De regulering voltrekt zich daarbij volgens twee stappen.

(1) Bepaal de som van kosten en maximaal toelaatbare winst die vereist is om de gevraagde hoeveelheid produkt te leveren.

(2) Stel zodanige tarieven vast dat hieruit inkomsten worden verkregen die voldoende zijn om het bedrag sub (1) op te brengen.

Een verkorte formulering van beide stappen luidt:

$$
\begin{aligned}
& \text { Vereiste inkomsten }=\text { kosten }+ \text { winst } \\
& (,, \text { revenue requirement" }=, \text {,cost of service" })
\end{aligned}
$$

Bij één produkt $(q=$ hoeveelheid; $p=$ prijs $)$ en een degressief verlopende kostenfunctie $\left(C=C(q)\right.$, waarbij $\left.\frac{d C}{d q}>0 ; \frac{d^{2} C}{d q^{2}}<0\right)$, terwijl de, ,rate of return" ( $r$ ) ter vereenvoudiging niet wordt gerelateerd aan het geïnvesteerde vermogen, maar aan de hoeveelheid (q), kan (3-1) als volgt worden herschreven:

$$
\mathrm{p} * \mathrm{q}=\mathrm{C}(\mathrm{q})+\mathrm{r} * \mathrm{q}
$$

waaruit volgt:

$$
\mathrm{p}=\frac{\mathrm{C}(\mathrm{q})}{\mathrm{q}}+\mathrm{r}
$$

ofwel: de prijs is gelijk aan de gemiddelde kosten vermeerderd met de per eenheid produkt gedefinieerde winstvoet die lager is dan maximaal mogelijk zou zijn.

\footnotetext{
${ }^{13}$ ) Uit deze formulering blijkt dat beide leden van de vergelijking via q interdependent zijn. Het is dan ook niet mogelijk, zoals hiervoor is gebeurd, twee afzonderlijke stappen te onderscheiden, één ter bepaling van de ,,cost of service" en één ter bepaling van de ,revenue requirement". Slechts een simultane oplossing van beide stappen biedt enig soelaas; zie verder par. 4.
}

$m a b$ blz. 536 


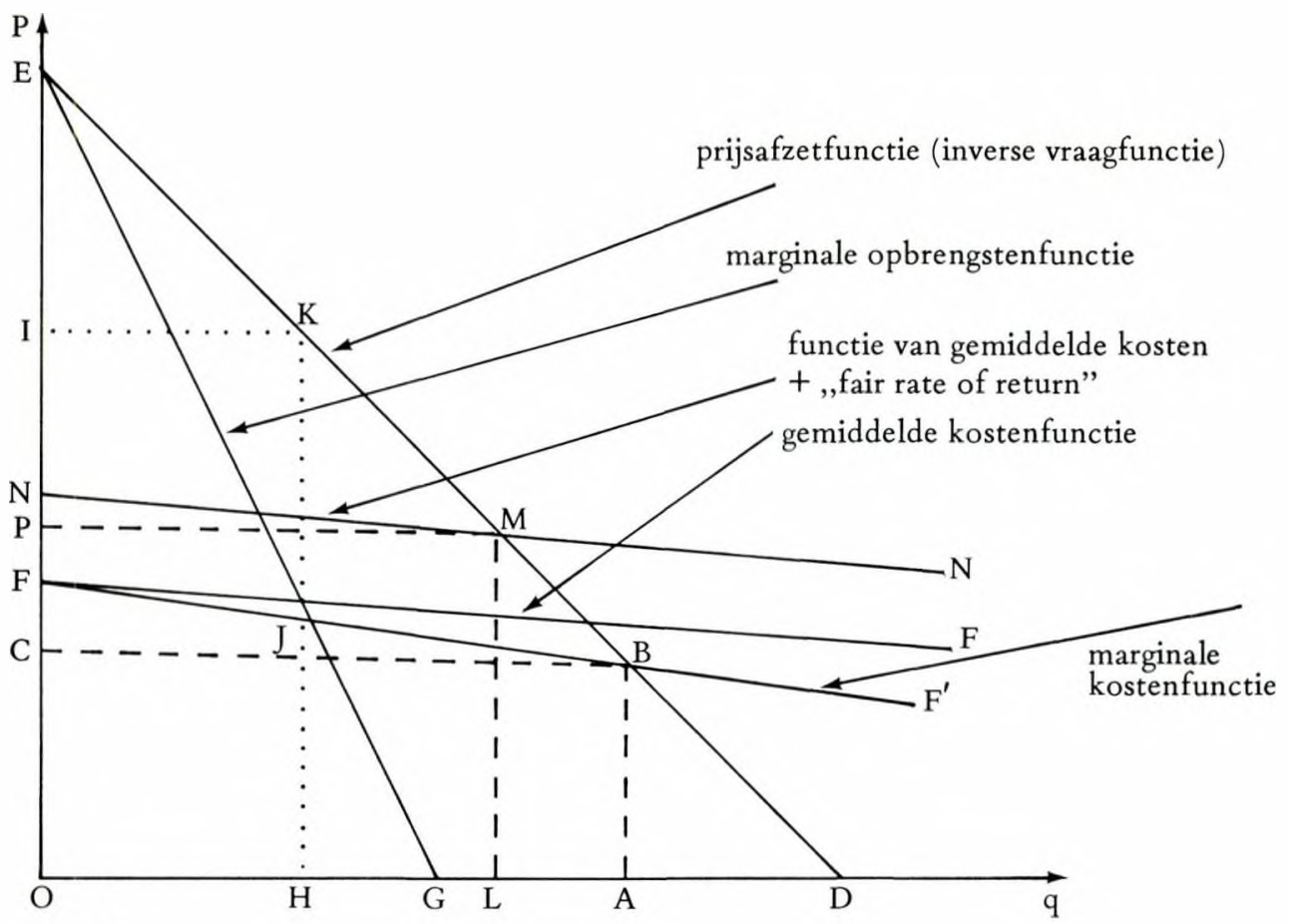

Figuur 3

In figuur 3 is deze prijszettingsoplossing grafisch weergegeven. Hierbij is $\mathrm{F}-\mathrm{F}^{\prime}$ de marginale kostenfunctie, $\mathrm{F}-\mathrm{F}$ de gemiddelde kostenfunctie en N-N de daarmee evenwijdige functie (3-3). De prijs is gelijk aan OP, bij een hoeveelheid OL. In figuur 3 zijn eveneens de winstmaximaliserende en de surplusmaximaliserende prijsstellingsoplossingen afgebeeld, zoals deze eerder in figuur 1 en 2 zijn afgeleid.

Een belangrijke vraag is natuurlijk hoe hoog de „fair rate of return" moet zijn. Uit Amerikaans onderzoek blijkt dat de ,,rate of return" voor openbare nutsbedrijven lager is dan die voor particuliere ondernemingen (respectievelijk 9,3 en $13,5 \%$ ). Wèl is de variatiebreedte aanzienlijk geringer (respectievelijk $8,0-10,1$ en $9,8-18,9 \%) .{ }^{1 ~}{ }^{4}$ ) In het algemeen is de ,, rate of return" voor openbare nutsbedrijven, waarin tevens de vermogenskosten zijn opgenomen, slechts weinig hoger is dan deze vermogenskosten; er is dus een kleine, hoewel vrij zekere, ,,overwinst".

\section{Specifieke implicaties voor de prijszetting bij een periodiek gedifferentieerde vraagstructuur}

Vrijwel alle openbare nutsbedrijven worden geconfronteerd met sterke periodieke vraagfluctuaties. Te denken valt hierbij aan vraagverschillen tussen dagen nachtperiode, werk- en weekend-dagen, of zomer- en winterseizoen, waar-

\footnotetext{
14) P. J. Garfield en W. F. Lovejoy, op. cit., blz. 26-27.
} 
bij voor elk onderscheid verdere verfijningen zijn aan te brengen (zoals dag-, avond- en nachtperiode). Naast deze periodieke vraagfluctuaties is sprake van de al eerder genoemde omstandigheid dat openbare nutsbedrijven veelal niet in staat zijn ,op voorraad" te produceren. Het zijn deze beide omstandigheden - periodieke vraagfluctuaties en de onmogelijkheid van produktie op voorraad - die enkele belangwekkende beleidsvraagstukken oproepen. Als we nl. in staat zijn de "totale vraagperiode" op te splitsen in enkele deelperioden, elk met hun eigen vraagspecificatie, dan kunnen we een simultane oplossing vinden voor een prijsdifferentiatie- en investeringsproblemen. Dat laatste nu is het verdere onderwerp van dit artikel. We zullen in par. 4.1. enkele alternatieve doelstellingsconstellaties introduceren. Vervolgens bezien we in par. 4.2. welke de prijszettingsimplicaties van deze doelstellingsconstellaties zijn. Hierbij bedienen we ons van een gestyleerd cijfervoorbeeld.

\subsection{Alternatieve doelstellingsconstellaties}

Alvorens te laten zien welke alternatieve doelstellingsconstellaties relevant kunnen zijn ingeval een oplossing moet worden gevonden voor het probleem van de periodieke prijsdifferentiatie, zullen we eerst aangeven van welke vooronderstellingen bij de mathematische formulering van dit probleem wordt uitgegaan.

- De vraagspecificatie. Er zijn n deelperioden van gelijke lengte, waarvoor de vraagfunctie $\mathrm{p}_{i}\left(\mathrm{q}_{\mathrm{i}}\right)$ lineair afnemend is; $\mathrm{dus} \frac{\mathrm{d} \mathrm{p}_{\mathrm{i}}}{\mathrm{dq}_{\mathrm{i}}}=\mathrm{c}_{\mathrm{i}}<0$, voor

$\mathrm{i}=1,2, \ldots, \mathrm{n}$, waarbij:

$\mathrm{p}_{\mathrm{i}}=$ prijs voor deelperiode $i$;

$\mathrm{q}_{\mathrm{i}}=$ gevraagde hoeveelheid in deelperiode $\mathrm{i}$.

Uit de vraagspecificatie $\mathrm{p}_{\mathrm{i}}\left(\mathrm{q}_{\mathrm{i}}\right)$ blijkt de aanname van periodieke onafhankelijkheid; immers voor de inverse van de vraagfunctie per deelperiode geldt:

$q_{1}=q_{1}\left(p_{1}\right), q_{2}=q_{2}\left(p_{2}\right) \ldots q_{n}=q_{n}\left(p_{n}\right)$ en niet:

$q_{1}=q_{1}\left(p_{1}, p_{2}, \ldots p_{n}\right), q_{2}=q_{2}\left(p_{1}, p_{2}, \ldots p_{n}\right) \ldots q_{n}=$

$=q_{n}\left(p_{1}, p_{2}, \ldots p_{n}\right)$.

- Gegeven de onmogelijkheid van produktie op voorraad zijn vraag en produktie identiek. Dus de variabele $q_{i}$ - hiervoor gedefinieerd als de vraag in deelperiode $\mathrm{i}$ - heeft eveneens betrekking op de produktie in deelperiode $\mathrm{i}$.

- De kostenspecificatie. Voor elke deelperiode i geldt:

$\mathrm{K}_{1}=\mathrm{bq}_{\mathrm{i}}+\beta \overline{\mathrm{q}}$ waarbij:

$\mathrm{K}_{\mathrm{i}}=$ kosten in declperiode $\mathrm{i}$;

$\mathrm{q}_{\mathrm{i}}=$ de te produceren hoeveelheid in deelperiode $\mathrm{i}$;

$\bar{q}=$ de op basis van de capaciteit maximaal te produceren hoeveelheid in deelperiode $\mathrm{i}$;

$\mathrm{b}=$ de variabele kosten, gerelateerd aan de produktie $\left(q_{i}\right) ;$

$\beta=$ de ,vaste" capaciteitskosten, gerelateerd aan de maximaal te produceren hoeveelheid $(\bar{q})$.

- Voor geen der deelperioden mag de feitelijke produktie groter zijn dan de maximale produktie, zodat moet gelden: $q_{i} \leqslant \bar{q}$ voor $i=1,2, \ldots$. 
Nog een tweetal opmerkingen ter nadere toelichting bij het bovenstaande. In de eerste plaats wordt uitgegaan van een lineaire kostenfunctie, hetgeen duidt op ,constant returns to scale". In de tweede plaats wordt aangenomen dat de grootheid $\overline{\mathrm{q}}$ (de capaciteit) continu varieerbaar is; dit impliceert de vooronderstelling van volledige deelbaarheid. Beide hier expliciet gemaakte vooronderstellingen doen enigszins afbreuk aan de in par. 2.1. van dit artikel geschetste eigenschappen van een natuurlijk monopolie, i.c. ,increasing returns to scale" en ,ondeelbaarheden". We menen deze inconsistentie in ons betoog te kunnen rechtvaardigen uit een oogpunt van - zoals men dat pleegt uit te drukken - ,analytical convenience". ${ }^{15}$ )

We hebben in par. 3.2. gesteld dat ,,rate of return"-regulering een in de praktijk veel voorkomende reguleringsvorm bij openbare nutsbedrijven is. Gegeven de in het voorgaande gedefinieerde functies en symbolen, luidt deze restrictie als volgt:

Som van opbrengsten over de deelperioden som van de variabele kosten over de deelperioden de capaciteitskosten $=$ winstplafond in de vorm van ,rate of return"

In symbolen:

$$
\sum_{i=1}^{n} p_{i}\left(q_{i}\right) * q_{i}-\sum_{i=1}^{n} b q_{i}-n \beta \bar{q}=n \alpha \bar{q}
$$

Hierbij wordt $\beta \bar{q}$ (de capaciteitskosten per deelperiode) vermenigvuldigd met n (het aantal deelperioden). Verder wordt de ,rate of return" (symbool: $\alpha$ ) gedefinieerd als fractie van de capaciteit $(\overline{\mathrm{q}})$, gesommeerd over $\mathrm{n}$ deelperioden. ${ }^{16}$ )

Gegeven de restrictie sub (4-2) kunnen verschillende doelstellingen worden genoemd, waarvan onderstaande wellicht het meest relevant zijn.

(1) Winstmaximalisatie

$$
\operatorname{Max} W=\sum_{i=1}^{n}\left[p_{i}\left(q_{i}\right)-b\right] q_{i}-n \beta \bar{q}
$$

(2) Omzetmaximalisatie

$$
\operatorname{Max} 0=\sum_{i=1}^{n} p_{i}\left(q_{i}\right) * q_{i}
$$

\footnotetext{
15) De gekozen optimaleringstechniek laat $\mathrm{nl}$. geen geheeltallige variabelen toc (ondeelbaarheden zijn hiermee uitgesloten), terwijl het vervangen van constante door vermeerderende schaalopbrengsten, hoewel niet onmogelijk, dan toch zeker ernstige complicaties oplevert. Bespreking van deze beide onderwerpen valt buiten het bestek van dit artikel. Zie verder G. J. van Helden, op. cit., par. IV. 2.3 en IV. 5.3.

16) Aangezien de ,rate of return" normaliter gedefinieerd wordt als fractie van het geinvesteerde vermogen, wordt met (4-2) impliciet een proportionele relatie tussen geinvesteerd vermogen en capaciteit aangenomen.
} 


$$
\operatorname{Max} A=\sum_{i=1}^{n} q_{i}
$$

waarbij als nadere restrictie zou kunnen worden opgenomen dat de prijs in geen der deelperioden kleiner mag zijn dan de variabele kosten, i.c. $\mathrm{p}_{\mathrm{i}} \geqslant \mathrm{b}$, voor $\mathrm{i}=1,2, \ldots \mathrm{n}$.

Om de prijszettingsimplicatie van deze drie gevallen op hun juiste waarde te kunnen beoordelen, definiëren we voorts een tweetal ,,referentiegevallen”: (a) maximalisatie van het maatschappelijk surplus als welvaartseconomische doelstelling; ${ }^{7}$ )

(b) winstmaximalisatie (voor het geval het monopolie niet zou worden gereguleerd).

We hebben aldus een aantal maximalisatieproblemen gedefinieerd, die in het algemeen de volgende gedaante hebben.

- Er is een doelstellingsfunctie die gemaximaliseerd moet worden.

- Er is een aantal beperkingen:

- voor alle gevallen is er de beperking dat de vraag in enige deelperiode niet groter mag zijn dan de beschikbare capaciteit: $\bar{q}-q_{i} \geqslant 0$, voor $i=1,2, \ldots . n$;

- voor de gevallen (1), (2) en (3) moet voorts aan de ,fair rate of return"restrictie sub (4-2) worden voldaan;

- voor geval (3) geldt bovendien: $p_{i}-b \geqslant 0$, voor $i=1,2, \ldots n$.

Op grond van deze beschrijving kunnen we concluderen dat we te maken hebben met een aantal ,constrained maximizing"-problemen, waarbij de beperkingen zowel voorkomen in de vorm van gelijkheden als in de vorm van ongelijkheden. De eerste-orde-voorwaarden van dergelijke problemen duidt men aan als de ,Kuhn-Tuckercondities". In de appendix bij dit artikel worden de betrokken voorwaarden voor één der maximalisatieproblemen bij wijze van voorbeeld afgeleid. Voor de resterende gevallen wordt volstaan met de formule van de optimale prijszettingsregel. ${ }^{18}$ ) In de volgende en laatste paragraaf van dit artikel worden de prijszettingsconsequenties van de hiervoor geintroduceerde gevallen weergegeven en onderling vergeleken aan de hand van een cijfervoorbeeld.

17) In formule-vorm: $\operatorname{Max} M S=\sum_{i=1}^{n} j_{0}^{q_{i}} p_{i}\left(q_{i}\right) d q_{i}-\sum_{i=1}^{n} b q_{i}-n \beta \bar{q}$

18) De onderhavige problematiek vindt men terug in een lange reeks van tijdschriftpublikaties, voornamelijk van welvaartseconomische aard. De grondleggers van de theorie der periodieke prijsdifferentiatie (,,peak load pricing”) zijn Boiteux en Steiner; zie M. Boiteux, Peak Load Pricing, Journal of Business, 1960, blz. $157-179$ (d.i. de vertaling van een Franstalig artikel uit 1949); P. O. Steiner, Peak Loads and Efficient Pricing, Quarterly Journal of Economics, 1957, blz. 585-610. Enkele meer recente publikaties zijn: E. E. Bailey, Peak Load Pricing under Regulatory Constraint, Joumal of Political Economy, 1972, blz. 662-679; S. C. Littlechild, Peak Load Pricing of Telephone Calls, Bell Journal of Economics and Management Science, 1970, blz. 191-210; I. Pressman, A Mathematical Formulation of the Peak Load Pricing Problem, Bell Journal of Economics and Management Science, 1970, blz. 304-326; O. E. Williamson, Peak Load Pricing and Optimal Capacity under Indivisibility Constraints, American Economic Review, 1966, blz. 810-827. Zie voor een overzicht verder G. J. van Helden, op. cit., hoofdstuk IV.

$m a b$ blz. 540 


\subsection{Interpretatie van de verschillen aan de hand van een cijfervoorbeeld}

Stel dat we een etmaal in drie deelperioden van gelijke lengte (i.c. elk 8 uren) kunnen opdelen, waarvoor de vraagspecificaties als volgt luiden.

(1) $\mathrm{q}_{1}=-2 \mathrm{p}_{1}+70 \rightarrow \mathrm{p}_{1}=-\frac{1}{2} \mathrm{q}_{1}+35$
(2) $\mathrm{q}_{2}=-2 \mathrm{p}_{2}+90 \rightarrow \mathrm{p}_{2}=-\frac{1}{2} \mathrm{q}_{2}+45$
(3) $\mathrm{q}_{3}=-2 \mathrm{p}_{3}+110 \rightarrow \mathrm{p}_{3}=-\frac{1}{2} \mathrm{q}_{3}+55$

(middel-hoog)

(hoog)

Deze vraagspecificaties verschillen uitsluitend voor wat betreft de ,,constante"; de helling is voor alle drie functies dezelfde. Voorts nemen we aan dat de variabele kosten gelijk zijn aan 5 per eenheid, terwijl de capaciteitskosten 6 per eenheid per deelperiode bedragen. De kostenfunctie per deelperiode luidt dan:

$$
\mathrm{K}_{\mathrm{i}}=5 \mathrm{q}_{\mathrm{i}}+6 \frac{2}{3} \overline{\mathrm{q}} \quad \text { voor } \mathrm{i}=1,2,3 .
$$

In de tabel hierna zijn voor elk van de in par. 4.1. onderscheiden doelstellingsconstellaties de prijszettingsconcequenties voor het cijfervoorbeeld weergegeven. Tevens is steeds voor elk der doelstellingsconstellaties aangegeven hoe groot afzet, omzet, winst en maatschappelijk surplus zijn.

Het is weinig zinvol de tabel uitkomst voor uitkomst na te lopen. We beperken ons tot enkele saillante eigenschappen van de door elk der doelstellingsconstellaties gegenereerde resultaten.

- De beide referentiegevallen - surplusmaximalisatie (a) en winstmaximalisatie (b) - vormen twee uitersten, waarbinnen de resultaten (in het bijzonder met betrekking tot de winst en het surplus) van de andere gevallen liggen. Wanneer we winstmaximalisatie en surplusmaximalisatie onderling vergelijken, dan blijken de respectievelijke verschillen te bestaan in: hogere prijzen voor alle deelperioden, een hogere omzet en winst, maar een lagere afzet en surplus.

- Winstmaximalisatie onder een ,fair rate of return"-beperking (1) blijkt enkele opvallende uitkomsten op te leveren. Naarmate de winstrestrictie minder stringent wordt, hetgeen tot uitdrukking komt in een lagere waarde van $\alpha$, wordt de prijs in de spitsperiode (3) verlaagd, terwijl die in de beide andere perioden hun winstmaximaliserende niveau behouden. ${ }^{19}$ ) Deze verlaging van de ,spitsprijs" kan in extreme gevallen zelfs van zodanige aard zijn dat deze lager komt te liggen dan de prijs in een niet-spitsperiode; in de tabel wordt deze situatie geillustreerd voor het geval dat $\alpha 5$ is. De vraag rijst op welke wijze deze prijszettingsconsequenties kunnen worden verklaard. Deze vraag laat zich vrij eenvoudig beantwoorden. De naar maximale winst strevende monopolist zal, indien hij met een „fair rate of return"-restrictie wordt geconfronteerd, trachten het geïnvesteerde vermo-

19) Hierbij geldt voor periode 2 dat het winstmaximaliserende niveau van de prijs $27 \frac{1}{2}$ is, indien de betrokken deelperiode bijdraagt in de capaciteitskosten - zie geval (b) - terwijl deze 25 is, indien zulks niet het geval is - zie geval (1) bij $\alpha=5$ of $\alpha=10$; voor $\alpha=15$ (bij geval 1) draagt de prijs van periode 2 voor een deel bij in de capaciteitskosten: $\mathrm{p}_{2}=26,4$. Periode 1 draagt nooit bij in de capaciteitskosten, op grond waarvan - zowel voor geval (b) als voor geval (1), ongeacht de waarde van $\alpha$-een prijs van 20 wordt genoteerd. 
Tabel Prijszettingsimplicaties bij verschillende doelstellingsconstellaties

\begin{tabular}{|c|c|c|c|c|c|c|c|}
\hline Doelstellingsconstellatie & $p_{1}-q_{1}$ & $\mathrm{P}_{2}-\mathrm{q}_{2}$ & $p_{3}-q_{3}$ & afzet & omzet & winst & surplus \\
\hline $\begin{array}{l}\text { Zonder winstrestrictie } \\
\text { (a) Maximalisatie maat- } \\
\text { schappelijk surplus }\end{array}$ & $5-60$ & $10-70$ & $20-70$ & 200 & 2400 & 0 & 3350 \\
\hline (b) Winstmaximalisatie & $20-30$ & $27 \frac{1}{2}-35$ & $37 \frac{1}{2}-35$ & 100 & 2875 & 1675 & 2513 \\
\hline 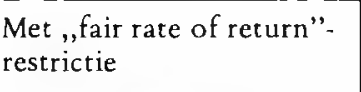 & & & & & & & \\
\hline $\begin{array}{l}\text { (1) Winstmaximalisatie } \\
\text { bij } \alpha=5 \\
\text { bij } \alpha=10 \\
\text { bij } \alpha=15\end{array}$ & $\begin{array}{l}20-30 \\
20-30 \\
20-30\end{array}$ & $\begin{array}{c}25-40 \\
25-40 \\
26,4-37,1\end{array}$ & $\begin{array}{c}21,4-67,2 \\
30-50 \\
36,4-37,1\end{array}$ & $\begin{array}{l}137 \\
120 \\
104\end{array}$ & $\begin{array}{l}3038 \\
3100 \\
2934\end{array}$ & $\begin{array}{l}1008 \\
1500 \\
1671\end{array}$ & $\begin{array}{l}2762 \\
2750 \\
2584\end{array}$ \\
\hline $\begin{array}{l}\text { (2) Omzetmaximalisatie*) } \\
\text { bij } \alpha=5 \\
\text { bij } \alpha=10 \\
\text { bij } \alpha=15\end{array}$ & $\begin{array}{c}16,4-37,2 \\
17,6-34,8 \\
18-34\end{array}$ & $\begin{array}{c}22,2-45,6 \\
23-44 \\
26,5-37\end{array}$ & $\begin{array}{l}21,8-66,4 \\
30,2-49,6 \\
36,5-37\end{array}$ & $\begin{array}{l}149 \\
128 \\
108\end{array}$ & $\begin{array}{l}3070 \\
3122 \\
2943\end{array}$ & $\begin{array}{r}996 \\
1488 \\
1663\end{array}$ & $\begin{array}{l}2983 \\
2890 \\
2637\end{array}$ \\
\hline $\begin{array}{l}\text { (3) Afzetmaximalisatie } \\
\text { bij } \alpha=5 \\
\text { bij } \alpha=10=5 \\
\text { bij } \alpha=15=1\end{array}$ & $\begin{array}{r}63-563 \\
113-47 \\
163-36\end{array}$ & $\begin{array}{l}16 \frac{2}{3}-56 \frac{2}{3} \\
21 \frac{2}{3}-47 \frac{2}{3} \\
26 \frac{2}{3}-36^{2}\end{array}$ & $\begin{array}{l}26 \frac{2}{3}-56 \frac{2}{3} \\
313-473 \\
36 \frac{2}{3}-36^{2}\end{array}$ & $\begin{array}{l}143 \\
110\end{array}$ & $\begin{array}{l}2834 \\
3099 \\
2934\end{array}$ & $\begin{array}{r}851 \\
1431 \\
1651\end{array}$ & $\begin{array}{l}3259 \\
3099 \\
2659\end{array}$ \\
\hline
\end{tabular}

*) Wegens rekentechnische complicaties moeten de hier gepresenteerde oplossingen worden opgevat als een benadering voor de optimale.

gen zo hoog mogelijk op te voeren. Immers, in dat geval zal de gegeven "fair rate of return" (zijnde een relatieve grootheid) tot een zo groot mogelijk (absoluut) winstbedrag leiden. Het zo hoog mogelijk opvoeren van het totale geinvesteerde vermogen laat zich het beste realiseren door stimulering van het spitsverbruik. Deze stimulering van het spitsverbruik zal maximaal zijn, indien in de andere deelperioden een zo hoog mogelijke winst wordt gerealiseerd. ${ }^{20}$ ) De spitsprijs kan dan eventueel verlaagd worden tot beneden het kostenniveau; de hierdoor ontstane ,onderdekking” wordt terugverdiend door de andere deelperioden. ${ }^{2}{ }^{1}$ )

- Onder omzetmaximalisatie bij een „,fair rate of return"-beperking (2) zien we dat een verlaging van $\alpha$ de periode-prijzen relatief dichter bij (en daarmee de afgezette hoeveelheden relatief verder van) elkaar brengt.

- Onder afzetmaximalisatie, gegeven een ,fair rate of return"-restrictie (3) wordt, ongeacht de waarde van $\alpha$, in elk der deelperioden dezelfde hoeveelheid afgezet; steeds geldt: $\mathrm{q}_{1}=\mathrm{q}_{2}=\mathrm{q}_{3}$. Klaarblijkelijk is het mogelijk de prijs in de dalperiode extra laag te houden (waardoor een grote afzet wordt bereikt), mits in de beide andere deelperioden voldoende wordt ,verdiend" om de nauwelijks aanwezige winstbijdrage van de dalperiode te compenseren. De prijs in de dalperiode ligt nl. steeds relatief verder van het winstmaximaliserende niveau dan de beide andere periode-prijzen.

20) Vgl. S. H. Wellisz, Regulation of Natural Gas Pipeline Companies; an Economic Analysis, Journal of Political Economy, 1963, blz. 30-43.

21) $\mathrm{Bij} \alpha=5$ is dit inderdaad het geval. De kostendekkende spitsprijs ligt bij $\mathrm{P}_{3}=\mathrm{b}+3 \beta=5+20=25$; de , fair rate of return"-prijs is hier 21,4 .

$m a b$ blz. 542 
Voor de doelstellingsconstellaties met een „,fair rate of return"-restrictie geldt in het algemeen nog het volgende. Naarmate $\alpha$ kleiner is:

- is de winst lager, hoewel minder dan proportioneel;

- is de afzet hoger, hoewel minder dan proportioneel;

- neemt de omzet eerst toe en daarna weer af;

- is het surplus hoger, hoewel minder dan proportioneel.

Met bovenstaand cijfervoorbeeld is slechts een enkele indicatie voor de hoogte van periode-prijzen gegeven. Voor het oplossen van problemen van periodieke prijsdifferentiatie in de praktijk zal men zich o.a. moeten bezinnen op de volgende probleemgebieden. ${ }^{2}{ }^{2}$ )

(a) De doelstellingsspecificatie (welke maximand en welke randvoorwaarden?).

(b) De vraagspecificatie. In vergelijking met het cijfervoorbeeld kunnen de volgende complicaties in ogenschouw worden genomen: deelperioden van ongelijke lengte, vraaginterdependenties tussen deelperioden, stochastische vraagrelaties.

(c) De kostenspecificatie, waarbij de belangrijkste complicatie zal bestaan in het evalueren van niet-lineaire kostencomponenten en ondeelbaarheden.

(d) De oplossingsmethode. In deze paragraaf is gekozen voor de traditioneelanalytische oplossingsmethode van de differentiaalrekening. Het grote nadeel van deze methode is dat slechts voorwaarden voor een optimum worden afgeleid, terwijl andere methoden, bijv. lineaire programmering, de optimale oplossing zelf genereren. Vooral bij meer complexe probleemspecificaties zal men het gebruik van deze numerieke methoden niet kunnen ontberen.

22) Nog afgezien van welvaartseconomische complicaties (o.a. externe effecten, naast beste-overwegingen). 


\section{Appendix}

We nemen als voorbeeld het streven naar maximale winst, indien voldaan moet zijn aan een "fair rate of return"-restrictie. Het maximalisatieprobleem luidt als volgt.

$$
\operatorname{Max} W=\sum_{i=1}^{p}\left[p_{i}\left(q_{i}\right)-b\right] q_{i}-n \beta \bar{q}
$$

onder voorwaarde dat: (1) $\mathrm{q}_{\mathrm{i}} \leqslant \overline{\mathrm{q}}$ voor $\mathrm{i}=1,2, \ldots \mathrm{n}$

$$
\text { (2) }(\beta+\alpha) n \bar{q}+\sum_{i=1}^{n} b q_{i}-\sum_{i=1}^{n} p_{i}\left(q_{i}\right) * q_{i}=0
$$

Hierbij is (a-3) de herschreven versie van de ,fair rate of return"-restrictie, zoals deze in par. 4.1 . onder $(4-2)$ is geformuleerd.

De Langrange-vorm van het maximalisatieprobleem sub $(a-1),(a-2)$ en (a-3) ziet er dan als volgt uit.

$$
\begin{aligned}
& \operatorname{Max}_{\mathrm{q}_{\mathrm{i}}, \overline{\mathrm{q}}, \lambda_{\mathrm{i}}, \mu} \quad \mathrm{LW}=\sum_{\mathrm{i}=1}^{\mathrm{n}}\left[\mathrm{p}_{\mathrm{i}}\left(\mathrm{q}_{\mathrm{i}}\right)-\mathrm{b}\right] \mathrm{q}_{\mathrm{i}}-\mathrm{n} \beta \overline{\mathrm{q}}+\sum_{\mathrm{i}=1}^{\mathrm{n}} \lambda_{\mathrm{i}}\left(\overline{\mathrm{q}}-\mathrm{q}_{\mathrm{i}}\right)+ \\
& (\mathrm{i}=1,2, \ldots \mathrm{n}) \\
& \mu\left\{(\beta+\alpha) \mathrm{n} \overline{\mathrm{q}}+\sum_{\mathrm{i}=1}^{\mathrm{n}} \mathrm{bq}_{\mathrm{i}}-\sum_{\mathrm{i}=1}^{\mathrm{n}} \mathrm{p}_{\mathrm{i}}\left(\mathrm{q}_{\mathrm{i}}\right) * \mathrm{q}_{\mathrm{i}}\right\}
\end{aligned}
$$

Hierbij zijn $\lambda_{i}(i=1,2, \ldots n$ ) en $\mu$ Langrange-multiplicatoren. De KuhnTucker-voorwaarden voor dit probleem worden geschreven als:

$$
\begin{aligned}
& \frac{\partial L W}{\partial q_{i}} \leqslant 0 \Rightarrow q_{i} \frac{d p_{i}}{d q_{i}}+p_{i}-b-\lambda_{i}+\mu\left(b-q_{i} \frac{d p_{i}}{d q_{i}}-p_{i}\right) \leqslant 0= \\
& p_{1} \leqslant b-q_{i} \frac{d p_{i}}{d q_{i}}+\frac{\lambda_{i}}{(1-\mu)} \quad(i=1,2, \ldots n) \\
& q_{1} \frac{\partial L W}{\partial q_{i}}=0 \Rightarrow q_{i}\left\{(1-\mu)\left(p_{i}+q_{i} \frac{d p_{i}}{d q_{i}}-b\right)-\lambda_{i}\right\}=0 \\
& (i=1,2, \ldots n) \\
& \frac{\partial L W}{\partial \bar{q}} \leqslant 0 \Rightarrow-n \beta+\sum_{i=1}^{n} \lambda_{i}+\mu\{(\beta+\alpha) n\} \leqslant 0 \\
& \bar{q} \cdot \frac{\partial L W}{\partial \bar{q}}=0 \Rightarrow \bar{q}\left[-n \beta+\sum_{i=1}^{n} \lambda_{i}+\mu\{(\beta+\alpha) n\}\right]=0 \\
& \frac{\partial L W}{\partial \lambda_{i}} \geqslant 0 \Rightarrow\left(\bar{q}-q_{i}\right) \geqslant 0 \quad(i=1,2, \ldots n) \\
& \lambda_{i} \frac{\partial L W}{\partial \lambda_{i}}=0 \Rightarrow \lambda_{i}\left(\bar{q}-q_{i}\right)=0 \quad(i=1,2, \ldots n)
\end{aligned}
$$




$$
\frac{\partial L W}{\partial \mu}=0 \Rightarrow(\beta+\alpha) n \bar{q}+\sum_{i=1}^{n} b q_{1}-\sum_{i=1}^{n} p_{i}\left(q_{i}\right)+q_{i}=0
$$

en verder de non-negativiteitsvoorwaarden:

$$
\mathrm{q}_{\mathrm{i}}, \lambda_{\mathrm{i}} \geqslant 0 \quad(\mathrm{i}=1,2, \ldots \mathrm{n}) ; \quad \overline{\mathrm{q}}, \mu \geqslant 0
$$

Een beknopte interpretatie van deze (eerste orde)voorwaarden voor het maximum van LW is hier op zijn plaats. ${ }^{24}$ ) We maken hiertoe een onderscheid tussen dal- en spitsperiode.

(a) In de dalperiode wordt de capaciteit niet volledig benut: $\mathrm{q}_{\mathrm{i}}<\overline{\mathrm{q}}$.

Op basis van $(a-10)$ moet dan gelden: $\lambda_{i}=0$. Ervan uitgaande dat $q_{i}>0$ zal volgens $(a-5)$ en $(a-6)$, en bij $\lambda_{i}=0$, dan de volgende prijszettingsregel gelden:

$$
\mathrm{p}_{\mathrm{i}}=\mathrm{b}-\mathrm{q}_{\mathrm{i}} \frac{\mathrm{dp_{i }}}{\mathrm{dq}}
$$

(b) In de spitsperiode wordt de capaciteit wèl volledig benut: $q_{i}=\bar{q}$. Het valt te bewijzen dat in zo'n geval $\lambda_{i}$, die kan worden opgevat als de ,,schaduwprijs" voor een capaciteitsuitbreiding, positief moet zijn. Gegeven $\lambda_{i}>0$ en $q_{i}>0$, geldt volgens $(a-5)$ en $(a-6)$ :

$$
\mathrm{p}_{\mathrm{i}}=\mathrm{b}-\mathrm{q}_{\mathrm{i}} \frac{\mathrm{d} \mathrm{p}_{\mathrm{i}}}{\mathrm{dq}}+\frac{\lambda_{\mathrm{i}}}{(1-\mu)}
$$

Voor alle andere, in par. 4.1. geïntroduceerde doelstellingsconstellaties kunnen analoge afleidingen van de eerste orde-voorwaarden worden gegeven. We volstaan hier met de presentatie van de dal- en spitsprijs, overeenkomstig de in deze appendix gegeven definitie, voor alle besproken doelstellingsconstellaties; zie volgende tabel.

23) De „fair rate of return"-restrictie wordt hiermee opgevat als een gelijkheidsbeperking, dit in tegenstelling tot de vraag-produktiebeperking die wordt opgevat als een ongelijkheidsrestrictie. Vergelijk (a-11) met (a-9) en (a-10).

24) Voor een nadere uiteenzetting over de hier gehanteerde wiskundige techniek, zie bijv. K. Lancaster, Mathematical Economics, New York: McMillan, 1969, hfdst. 5; zie ook G. J. van Helden, op. cit., Appendix A. Impliciet wordt aangenomen dat aan de tweede-orde-voorwaarden voor een maximum is voldaan. 
Tabel Spits- en dalprijs bij verschillende doelstellingsconstellaties

\begin{tabular}{|c|c|c|}
\hline Doelstellingsconstellatie & Spitsprijs & Dalprijs \\
\hline $\begin{array}{l}\text { Zonder winstrestrictie } \\
\text { (a) Maximalisatie van het } \\
\text { maatschappelijk } \\
\text { surplus }\end{array}$ & $\mathrm{P}_{\mathrm{i}}=\mathrm{b}+\lambda_{\mathrm{i}}$ & $\mathrm{p}_{\mathrm{i}}=\mathrm{b}$ \\
\hline (b) Winstmaximalisatie & $p_{i}=b+\lambda_{i}-q_{i} \frac{d p_{i}}{d q_{i}}$ & $\mathrm{p}_{\mathrm{i}}=\mathrm{b}-\mathrm{q}_{\mathrm{i}} \frac{\mathrm{d} \mathrm{p}_{\mathrm{i}}}{\mathrm{d} \mathrm{q}_{\mathrm{i}}}$ \\
\hline $\begin{array}{l}\text { Met ,fair rate of return"- } \\
\text { restrictie } \\
\text { (1) Winstmaximalisatie }\end{array}$ & $\mathrm{p}_{\mathrm{i}}=\mathrm{b}+\frac{\lambda_{\mathrm{i}}}{1-\mu}-\mathrm{q}_{\mathrm{i}} \frac{\mathrm{dp_{i }}}{\mathrm{dq}_{\mathrm{i}}}$ & $\mathrm{p}_{\mathrm{i}}=\mathrm{b}-\mathrm{q}_{\mathrm{i}} \frac{\mathrm{d} \mathrm{p}_{\mathrm{i}}}{\mathrm{dq}_{\mathrm{i}}}$ \\
\hline (2) Omzetmaximalisatie & $\mathrm{p}_{\mathrm{t}}=\frac{\lambda_{\mathrm{i}}-\mathrm{b} \mu}{1-\mu}-\mathrm{q}_{\mathrm{i}} \frac{\mathrm{d} \mathrm{p}_{\mathrm{i}}}{\mathrm{dq_{i }}}$ & $\mathrm{p}_{\mathrm{i}}=\frac{-\mathrm{b} \mu}{1-\mu}-\mathrm{q}_{\mathrm{i}} \frac{\mathrm{d} \mathrm{p}_{\mathrm{i}}}{\mathrm{dq_{i }}}$ \\
\hline (3) Afzetmaximalisatie*) & $\mathrm{p}_{\mathrm{i}}=\mathrm{b}+\frac{1-\lambda_{\mathrm{i}}}{\mu}-\mathrm{q}_{\mathrm{i}} \frac{\mathrm{d} \mathrm{p}_{\mathrm{i}}}{\mathrm{dq}_{\mathrm{i}}}$ & $\mathrm{p}_{\mathrm{i}}=\mathrm{b}+\frac{1}{\mu}-\mathrm{q}_{\mathrm{i}} \frac{\mathrm{dp_{ \textrm {i } }}}{\mathrm{dq}_{\mathrm{i}}}$ \\
\hline
\end{tabular}

*) Hierbij is afgezien van de restrictie dat $p_{j}$ groter moet zijn dan b. 